\title{
A Sociological Study on the Modern Changes within the Rodi Caste Community in Sri Lanka
}

\author{
Dr Geethani Amaratunga \\ Senior Lecturer, Department of Sociology, University of Kelaniya, Sri Lanka
}

\begin{abstract}
This study discusses the changes and challenges faced in the present day by the Rodi Community in Sri Lanka. A caste system is a common feature in South Asian societies. This social stratification feature was found in Sri Lankan society since ancient times.

Sri Lanka has many castes within the caste hierarchy, the Rodi community being right at the bottom. Their numbers are the lowest.

Their fall from grace within the Sri Lankan society in ancient times is attributed to supplying the King's palace with human flesh instead of venison(Knox, 1981:70) Walking the streets, begging and receiving the brunt of other caste members' derision, disgust and revulsion has been part and parcel of life during ancient times. In the present day, the socio-economic conditions of this community have faced many changes. This research study aims to identify the changes which have taken place within the Rodi community and study them further.

During the time of British rule, with concepts such as equality, acceptance and human rights making a presence within Sri Lanka society, traditional lives and livelihoods of the Rodi people were directly impacted. These changes over the years have been responsible in creating a new image for this community which was shunned by the majority. This study hopes to explore the hypothesis, 'the cultural practices of Rodi people have faced many changes and challenges,' as well as delve into the changes which have taken place from ancient times to the present day.
\end{abstract}

Keywords: rodi community, caste system, caste hierarchy one, two, three, etc. (Use "keywords" style)

\section{Introduction}

Social stratification, also identified as the caste system, is a unique feature in south Asian societies. Since ancient times the caste system has been a prevalent and powerful factor in Indian society. It is believed that due to Indian influence, social stratification has spread to Sri Lankan society as well.

However, it must be noted that the stratification in Sri Lanka is not as rigid as it is in India, Sri Lanka being a country vastly influenced by Buddhism which rejects inequalities such as the caste system. While 16 castes can be identified within Sri Lankan society, the Rodi caste is at the bottom of this stratification. The Rodi caste has been discriminated against by the rest of the castes. This research study hopes to identify the changes the Rodi people are facing in modern times.

\section{Research Background}

The Rodi community has played a prominent role in the Sri Lankan society from ancient times. Even though they are small in numbers, special attention and awareness have been paid by other clans towards this community. As the Rodi people are at the bottom of the caste hierarchy, it is clear that the other clans have no reservations about showing their revulsion and disgust towards them.

In ancient times the job description of Rodi people was to supply the King's palace with venison. One day instead of venison the Rodi hunter surreptitiously supplied the royal household with human flesh which the King in his ignorance relished during his meal. Although King Parakramabahu's daughter Ratnavalli discovered the gruesome secret, she encouraged the hunter to continue supplying human flesh.

As time went on the King discovered the horrific secret, he in his rage disowned his daughter, stripped her of her royal entitlements and jewellery, gave her in marriage to the venison hunter, replaced her royal garb with rags and sent her to live with the Rodi clan, stating that death was too good a punishment for her and banished her from the palace. 
The royal decree was that they cannot engage in any trade or livelihood in all generation to come, that they should roam throughout the kingdom begging from the rest for their survival and he ordered that they should be discriminated against and treated with revulsion and disgust. Accordingly this community is found throughout Sri Lanka in small numbers.

Social stratification is an inimitable feature in south Asian societies, this can be identified as the caste system. In India the caste system is quite rigid in its rules and it has been a prevalent and powerful factor in their society. Caste system in India is a social institution strongly interlinked with Hinduism.

In India, caste is identified under two names, which are Varna and Jati. Varna is a system deeply intertwined with Hinduism. The entire Hindu society is divided into four segments that is Brahmin, Kshatriya, Vaishiya and Shudra. When studying the Hindu society, although the Varna system is important, it is the Jati system that is in use practically in the Indian social institution. Jati system though linked to the Varna system is a more complex division of classes. In India there would be many different Jati divisions throughout the country(Dube,1990:48).

Sociologist Srinivas, identified that in one geographical area where one language was spoken, there would be over 2000 Jati divisions. (Srinivas,1952)Jati or castes are many in India.

According to Varna division system, Brahmins are at the top tier in society while the Kshatriya and Vaishya come in second and third tiers respectively. Shudra is considered to be the lowest at the bottom of the hierarchy, while they are considered to be unclean, of a low birth and low social standing they have no choice but to live a life of servitude to the other castes.

In Indian society they are known as the 'untouchables' the other castes didn't even want to come across anyone belonging to this social category. This group of people are known as Dalits and they represent $16 \%$ of the Hindu population (Dube; 1990; p49). Their work involves, removing dead bodies, removing garbage, removing urine and faeces as well as working in leather tanneries, which were deemed unclean by the other varna/castes which further established their status as untouchables. The untouchables or Shudra's of India are very similar to the Rodi people of Sri Lanka. In ancient times seeing a Rodi person, marrying into that community, sharing a meal with them carried a heavy social stigma.

In India, the Shudra's occupy the last tier in the Varna social stratification system, Chandala's who originate from the Shudra's are also a low caste group of people in India. Chandala's too should not come into physical contact with the higher castes. Chandala's should build their houses away from everyone else's while performing community work such as performing last rites for unclaimed bodies of the dead. During the early Anuradhapura period, it has been recorded that Chandala community migrated and lived in Sri Lanka. It is understood that their lifestyle hadn't changed even though they lived here (Geiger; 1960 p.34).

The term Chandalayas are used even in present day to identify Rodi people, this is an indication that the Rodi caste and Chandala caste may have had a connection and similarities. Even though in ancient times these people received the brunt of society's scorn disgust and ridicule, it is clear that in the present day their lives have been transformed in all aspects such as social, economic, political and cultural.

\section{Research Problem}

It is understood that the Rodi caste has been around since the reign of King Parakramabahu, however, their presence in the annals of history starts much earlier. As early inhabitants, this community of people have evolved with time, their traditions, cultural practices, social structures, attire, matrimonial practices and language has been subject to change. Therefore the research problem which was faced was to identify the nature of change within this community in the present day.

\section{Objectives of the study}

The main objective of this study is to find out if the Rodi community has modernized along with the rest of the society. If so what are the visible changes?

The recognition which the Rodi people are given in terms of social, political, educational and cultural differences can be observed and quantified. In the past anthropologists mainly studied their genesis, the nature of their cultural practices, their civilization and the ritualistic practices that surround their social structure. 
However, in the present day they are fast disappearing into society and morphing into the majority population. With that their centuries old practices and identity is disappearing, the reason for their disappearance is also another area which this study hopes to discover.

In ancient times the livelihood of Rodi people was to beg for a living. However, in the present day they are occupied with livelihoods of other castes. It is important to identify the industries and trades they have interchanged to. Another aim of this study was to identify the role and the condition of the Rodi man within his family and community as well as the role of the Rodi woman within her family, the lives of her children within the socio-economic framework. It is also important to find out the changes which have brought about upward social mobility to the Rodi community within a social context which values affluence over caste divisions.

\section{Limitations of the research}

The Rodi people are spread throughout the island and they are mostly found in Sabaragamuwa, Central, North Central, Uva and Southern provinces mainly.It is not possible to study the Rodi people residing throughout all provinces, for this reason, we have selected to study the Rodi villages in the North central provinces only.

\section{Research Methodology}

The details collected in a study are known as data and this can be divided into two groups depending on its nature.

\subsection{Primary Data}

The primary data are gathered within the study through interviews, observations and questionnaires.

\subsection{Secondary Data}

Secondary data are gathered through newspaper articles, journals, books as well as data gathered from the statistics department.

Depending on the nature of the data it can be divided into two groups and studied further, one is qualitative data and quantitative data (Sarantakos,1998; p26).

\subsection{Quantitative Data}

Quantitative data will give a numerical value to details about the Rodi community such as their population, education levels, economic status etc.

\subsection{Qualitative Data}

However, details such as the ideas and aspirations of the Rodi people, their traditions and cultural practices, language cannot be quantified numerically. These details are processed as qualitative data. Qualitative data collecting techniques used in this study are survey methods and caste study methods.

- A popular method to garner information and data in sociological research studies is the survey method. When there is a large population to study, surveys are the best way to gather information. According to Wiseman and Aron survey research is a method for collecting and analysing social data through a highly structured and often very detailed interview or questionnaires in order to obtain information from large numbers of respondents presumed to be representative of a specific population (Berger,2000; p188).

- Case study method was used in this research to collate data on the Rodi community's socio-economic status. This method was used in several provinces of the country. Apart from research survey method, gathering data through case studies were also used. This is a popular method used to obtain more qualitative data.

Case studies will help to analyse a person or a situation in an in depth manner (Desai and Potter, 2006; 200). In this study, case studies were used to identify the lifestyle of the Rodi people, their marriage practices and family unit, the present day challenges and their dealings with mass society. 


\section{Data Analysis}

Although Sri Lanka is an Island nation, it has a colourful diversity within its population density, the main constituents of the population consists of Sinhalese, Tamil and Muslim citizens. The majority population is the Sinhalese community, at a glance it is a complex society. The immediate differences of geography are one division which categorises the community as upcountry Sinhalese and low country Sinhalese.

The up country Sinhalese people have an inflated sense of self-worth and consider themselves to be a better community than the low country community. They are also very caste conscious and will consider it quite seriously.

The govi caste in the caste hierarchy of the Sinhalese community is the highest. However, this caste is further divided into up country govi and low country govi segments. The caste conscious social institution of the Sinhalese community had about 18 other castes apart from the govi caste, this was found in the ancient constitution of laws and rules (bananeethiniganduwa). According to that, the lowest caste was called Gardi and this was another name for the Rodi people. They were Sri Lanka's untouchables, the other castes were forbidden to come into physical contact with them.

There are many ideas as to how the word Rodi came into being. Upham speculates that they were mostly leprosy patients who were ostracized from society and ordered to live in the jungles. Since they were considered to be very ill - the Sinhalese term for which is 'Rogadhithayin' which became Rodi for ease of use. (Upham,1833: p351) Wilhem Geiger, Ferguson and Enriques believe that the word Rodi came about from the Sinhalese word Rodda which means remainder of kernel once the nutrients are drained(Geiger,1920, Enriques; 1999,Ferguson:1895).

According to census and statistics from 1901 and 1911 in Sri Lanka, there were a total of 1464 and 1572 individuals respectively. The following table will show the spread of the Rodi community in various provinces in the country.

TABLE I: Spread of the Rodi community as per Cencus of Cey lon 1901,1911

\begin{tabular}{|c|c|c|}
\hline Provinces & Year 1901 & Year 1911 \\
\hline Sabaragamuwa Province & 438 & 479 \\
\hline Central Province & 241 & 411 \\
\hline North Central Province & 379 & 391 \\
\hline Uva Province & 367 & 269 \\
\hline Southern Province & 42 & 22 \\
\hline Total & 1464 & 1572 \\
\hline
\end{tabular}

It is a difficult task to provide exact numbers of the Rodi community living in Sri Lanka in the present day. The figures would be an approximate estimate and not exact figures. In 1951, M. D. Raghavan who conducted an in depth study about the Rodi people published a book by the title, 'Some aspects of Rodiya and Kinnaraya in the New Lanka.' The census conducted by Raghavan is as follows:

TABLE II: The Rodi numbers as per M.D. Raghavan'e Handsome Beggars, 1952

\begin{tabular}{|c|c|}
\hline Province & Numbers \\
\hline Central Province & 350 \\
\hline Wayamba Province & 490 \\
\hline Sabaragamuwa Province & 1150 \\
\hline Uva Province & 1100 \\
\hline Western Province & 110 \\
\hline Southern Province & 22 \\
\hline Total & $\mathbf{3 1 2 2}$ \\
\hline
\end{tabular}

There are many reasons for the gradual disappearance from focus of the Rodi community as opposed to a multiplication as with other groups. The main reason for their dwindling numbers is during the time of the 
Kandyan kingdom they had to face many hardships harassment and torture. For this research study, Rodi village - Manawa situated in the North central province has been used. Presently there are 580 individuals living in that village. The following table gives a breakdown of genders of the village.

TABLE III: A sample population according to gender in the Manawa Rodi village

\begin{tabular}{|c|c|c|}
\hline Gender & Numbers & Percentage \\
\hline Male & 277 & $48.49 \%$ \\
\hline Female & 293 & $51.50 \%$ \\
\hline
\end{tabular}

The home of the Rodi individual was known as a Kuppayama during the past. Such were built away from the villages of the high caste members of society often in inaccessible places which weren't hospitable at all. During the time of the Kandyan kingdom, Rodi households were only allowed to have one rafter in their roofs and leaves and branches should make up the roof. The front door should be coconut frond covered deer pelt. However in the present day, they have moved away from the identifying markers of a Kuppayama and have assimilated to society and built their homes according to their wishes and ability. The following table and pie chart gives an insight into the nature of their dwellings.

TABLE IV: Nature of Rodi homes and their numbers

\begin{tabular}{|c|c|}
\hline Nature of homes & Numbers \\
\hline Houses made with bricks & 52 \\
\hline Wattle and daub huts & 29 \\
\hline Temporary huts & 18 \\
\hline Complete permanent homes & 18 \\
\hline Two storey homes & $\mathbf{1 1 8}$ \\
\hline Total number of homes & \\
\hline
\end{tabular}

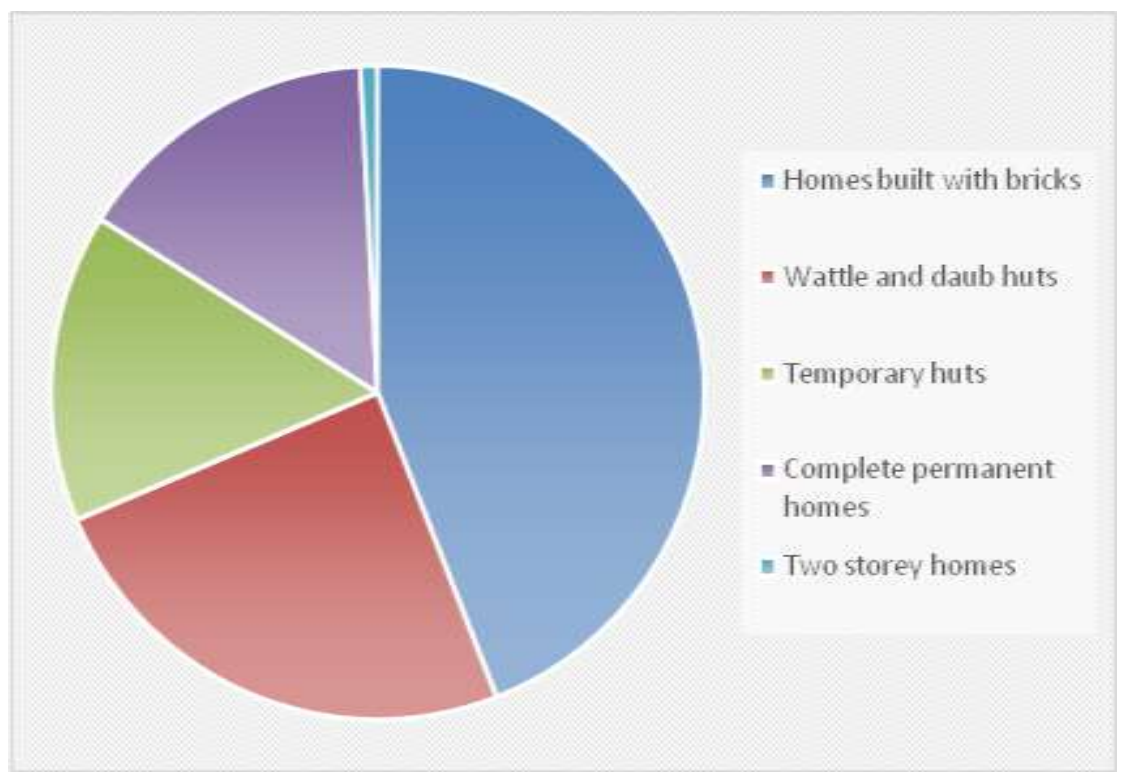

Fig. 1: "Nature of Rodi homes and their numbers"

In the past, the Rodi community were forbidden from building anything but Kuppayam habitats, however centuries later these attitudes have changed completely and it is heartening to see that these people have gone on to build even two storey homes. If one is to compare the outward appearance of a Rodi individual with a Sri Lankan, there is hardly any difference in physical stature or appearance. In the early $20^{\text {th }}$ century Rodi women had to bare their upper bodies as per royal decree of many centuries ago. This bared upper body was a clear 
indication of their Rodi community status. In the past, this baring of their upper body resulted in these women attracting sexual predators who in turn molested and abused them. By mid- $20^{\text {th }}$ century the rules changed and they could dress as they wished. As a result in the present day Rodi women and men have intermarried into the mass society and they have lost their unique identity as Rodi community members. Majority of the Manawa village population are Buddhist by birth.

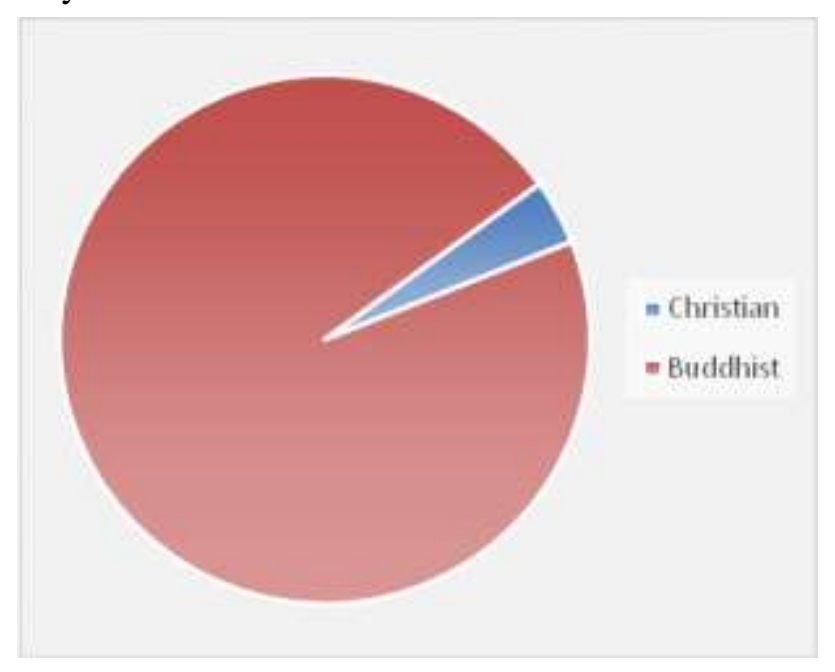

Fig. 2: "Population religion ratio of Manawa Rodi village"

From ancient times the Rodi people were Buddhist by birth, however in a recent sweeping trend, not just the inhabitants of Manawa village but many in other areas have converted to Christianity. Even though the segment representing Christians is as low as $4 \%$ it must be noted that these people were Buddhist by birth.

According to Raghavan, during Sri Lanka's feudal past, each caste had a specific job to perform as dictated by their caste and social standing, as Rodi people were restricted from engaging in normal livelihoods such as farming, cultivation or any other industry, their lives depended entirely on begging. In ancient times, there would be villages established close to Rodi villages so that they can seek out their meals from these host villages.

In the present day, changes in the country have resulted in those from the Rodi community breaking free from the mental and physical shackles of their ancestors. Their choice in employment is an indicator of this.

TABLE V: Nature of current employment of Sample population

\begin{tabular}{|c|c|c|c|}
\hline \multirow{2}{*}{ Nature of employment } & \multicolumn{2}{|c|}{ Number of people } & \multirow{2}{*}{ Percentage } \\
\cline { 2 - 4 } & Female & 05 & $41.5 \%$ \\
\hline Trading goods & 12 & 06 & $14.6 \%$ \\
\hline Labourers & 00 & 01 & $12.2 \%$ \\
\hline Shop employees & 04 & 04 & $9.8 \%$ \\
\hline Cane goods manufacturer & 00 & 03 & $7.3 \%$ \\
\hline Carpet weavers & 00 & 02 & $4.9 \%$ \\
\hline Hospital employees & 00 & 01 & $9.8 \%$ \\
\hline Garment factory employees & 03 & $\mathbf{1 0 0}$ \\
\hline Total & \multicolumn{2}{|c|}{$\mathbf{4 1}$} & \\
\hline
\end{tabular}

Education was strictly out of bounds for Rodi people, because of society's poor assessment of this community, it was even forbidden for a child of this community to be entered into a government school. With the establishment of free education in Sri Lanka this situation has changed to a certain extent. When analysing the Manawa situation, it is apparent these children have received an opportunity to study. 
TABLE VI: Education level of sample population

\begin{tabular}{|c|c|c|c|}
\hline \multirow{2}{*}{ Level of education } & \multicolumn{2}{|c|}{ Number of people } & \multirow{2}{*}{ Percentage } \\
\cline { 2 - 4 } & Female & Male & $28 \%$ \\
\hline Grade 1-5 & 12 & 02 & $24 \%$ \\
\hline Grade 5-8 & 03 & 09 & $32 \%$ \\
\hline Grade 9-10 & 04 & 12 & $12 \%$ \\
\hline Up to O/L's & 02 & 04 & $4 \%$ \\
\hline $\begin{array}{c}\text { Never received an } \\
\text { education }\end{array}$ & 01 & 01 & $\mathbf{1 0 0}$ \\
\hline Total & $\mathbf{5 0}$ & \\
\hline
\end{tabular}

With data gathered from 50 respondents, it is apparent that there is a high percentage of Rodi children enrolling in school. Out of the study sample, one female and one male had not attended school. This is an indicator of the rapid changes in the social environment such as acceptance and tolerance.

\section{Conclusion}

This study has been able to identify many changes within the Rodi community in present day Sri Lanka. With people no longer performing cast specific jobs for many decades, the concept of caste is dying out; Hence, the society has structured itself into a class stratified society from a caste stratified one. The findings of this study infers that with the modernizing of society, restrictions and limitations faced by the Rodi in the past have become obsolete and that this once segregated community has now fully integrated into the mass society of Sri Lanka.

\section{References}

[1] Berger, A. A. (2000); Media and Communication Research Methods; New Delhi, Sage Publications

[2] Desai, Vandana and Potter B. Robert (2006) Doing Development Research; New Delhi; Vistaer Publications

[3] Dube, S. C. (1990); Indian Society; National Book Trust, India

[4] Enriques, C. M. (1999) Ceylon Past and Present; New Delhi, India

[5] Ferguson A. M. (1895), TheRodiyas of Ceylon in the Monthly Literary Register. Vol III No 10 Oct 1895.

[6] Geiger, Wilhelm (1920), The language of the Rodiyas in the Ceylon Antiquary and Literal Register Vol V, pt III.

[7] Geiger, Wilhelm (1960), Culture of Ceylon in Medieval times, Wiesbaden

[8] Kothari, C. R. (1999), Research Methodology, Methods and Techniques Second

[9] Knox,Robert,(1681). A Historical Relation on Ceylon,Colombo:Tisaraprakashakay

[10] Edition, New Delhi, VishvaPrakash Publishing

[11] Sarantokos, S. (1998); Social Research, London; McMillan Press Ltd.

[12] Srinivas M. N. (1952); Religion and society among the Coorgs of South India, Oxford. 